\title{
PENERAPAN MEDIA FILM PENDEK UNTUK MENINGKATKAN KEMAMPUAN MENULIS TEKS ESAI PADA PESERTA DIDIK KELAS XII MIPA 6 SMA NEGERI 1 PONTIANAK
}

\author{
Febriany I. Sau \\ SMP Negeri 6 Satu Atap Tilamuta \\ febrianyiwansau@gmail.com
}

\begin{abstract}
Abstrak
Penelitian Tindakan Kelas (PTK) ini dilaksanakan di SMA Negeri 1 Pontianak pada semester genap Tahun Pelajaran 2018-2019, tepatnya dilaksanakan pada Januari hingga Maret 2019. Subjek penelitian adalah kelas XII MIPA 6 yang berjumlah 35 Orang. Penelitian dilaksanakan dalam dua siklus, namun sebelum melaksanakan siklus I dan II, terlebih dahulu dilakukan prasiklus. Adapun masalah yang diangkat dalam penelitian ini (1) Perencanaan pelaksanaan pembelajaran, (2) Pelaksanaan Pembelajaran media film pendek, (3) Evaluasi hasil belajar, dengan kriteria penilaian klasikal yamg telah ditentukan pada siklus I sekurang-kurangnya $80 \%$ nilai siswa minimal 75 dan siklus II sekurang-kurangnya 90\% nilai siswa minimal 75 . Hasil penelitian menunjukkan bahwa (1) Perencanaan Pelaksanaan Pembelajaran (RPP) yang dibuat oleh guru mengalami peningkatan dari silkus I 98\% menjadi 100\% pada siklus II, (2) Penerapan media film pendek, peningkatannya dari $81 \%$ menjadi $100 \%$, (3) Evaluasi hasil belajar mengalami peningkatan siklus I $72 \%$ menjadi $100 \%$ pada siklus II.

Kata kunci: media, film pendek, teks esai
\end{abstract}

\begin{abstract}
This Classroom Action Research was carried out at SMA Negeri 1 Pontianak in the even semester of the 2018-2019 Academic Year, precisely carried out in January to March 2019. The research subjects were Grade XII Mathematics 6 totaling 35 people. The study was conducted in two cycles, but before carrying out the first and second cycles, pre-cycle was carried out. The problems raised in this study (1) Planning the implementation of learning, (2) Implementation of learning short film media, (3) Evaluation of learning outcomes, with classic assessment criteria that have been determined in the first cycle of at least $80 \%$ student grades of at least 75 and cycle II at least $90 \%$ student value of at least 75 . The results showed that (1) Learning Implementation Planning (RPP) made by teachers increased from silkus I $98 \%$ to $100 \%$ in cycle II, (2) The application of short film media , an increase from $81 \%$ to $100 \%$, (3) Evaluation of learning outcomes has increased the first cycle $72 \%$ to $100 \%$ in the second cycle.
\end{abstract}

Keywords: media, short films, essay text

\section{PENDAHULUAN}

Keterampilan berbahasa merupakan aspek kemampuan berbahasa yang menjadi sasaran tumpu. Oleh sebab itu, dalam dunia pendidikan para guru terus 
berupaya meningkatkan keberhasilan dalam pembelajaran bahasa melalui pencapaian kompetensi berbahasa, yakni menyimak, berbicara, membaca, dan menulis. Menulis salah satu aspek keterampilan berbahasa yang berkaitan dengan pengungkapan pikiran, gagasan, pendapat, dan perasaan. Keterampilan menulis sebagai keterampilan berbahasa yang bersifat produktif dan ekpresif merupakan salah satu kompetensi dasar berbahasa yang harus dimiliki peserta didik agar terampil berkomunikasi secara tertulis. Peserta didik akan terampil mengorganisasikan gagasan dengan runtut, menggunakan kosakata yang tepat dan sesuai, memperhatikan ejaan dan tanda baca yang benar, serta menggunakan ragam kalimat yang variatif dalam menulis jika memiliki kompetensi menulis yang baik.

Berdasarkan pengalaman dan pengamatan di kelas, ditemukan bahwa menulis menjadi suatu hal yang kurang diminati dan kurang mendapat respon yang baik dari peserta didik. Peserta didik tampak mengalami kesulitan ketika harus menulis, tidak tahu apa yang harus dilakukan ketika pembelajaran menulis dimulai. Peserta didik terkadang sulit sekali menemukan kalimat pertama untuk memulai paragraf, takut salah, takut berbeda dengan yang diinstruksikan gurunya. Sehingga menyebabkan banyak peserta didik yang belum mencapai Kriteria Ketuntasan Minimal (KKM) yakni 75.

Kecenderungan lain yang terjadi adalah pola pembelajaran menulis di kelas yang dikembangkan dengan sangat terstruktur dan mekanis, mulai dari menentukan topik, membuat kerangka, menentukan ide pokok paragraf, kalimat utama, kalimat penjelas, ketepatan penggunaan pungtuasi dan sebagainya.

Pola tersebut selalu berulang tiap kali pembelajaran menulis. Pola tersebut tidak salah, tetapi pola itu menjadi kurang bermakna jika diterapkan tanpa variasi strategi dan teknik lain. Akibatnya, waktu pembelajaran pun lebih tersita untuk kegiatan tersebut, sementara kegiatan menulis yang sebenarnya tidak terlaksana atau sekedar menjadi tugas di rumah. Kegiatan menulis seperti ini bagi peserta didik menjadi suatu kegiatan yang prosedural dan menjadi tidak menarik.

Permasalahan di atas terjadi juga pada pembelajaran materi teks esai di kelas XII MIPA 6 SMA Negeri 1 Pontianak, berdasarkan masalah tersebut, peneliti melakukan satu inovatif dalam pembelajaran menulis teks esai, sehingga peserta didik mampu mencapai Kriteria Ketuntasan Minimal (KKM) yaitu 75 serta membuat pembelajaran lebih menyenangkan yakni dengan menggunakan salah satu media pembelajaran yaitu film pendek.

Media pembelajaran adalah paduan antara bahan dan alat atau perpaduan antara software dan hardware (Sadiman, dkk, 1996: 5). Media pembelajaran bisa dipahami sebagai media yang digunakan dalam proses dan tujuan pembelajaran. Pada hakikatnya proses pembelajaran juga merupakan komunikasi, maka media pembelajaran bisa dipahami sebagai media komunikasi yang digunakan dalam proses komunikasi tersebut, media pembelajaran memiliki peranan penting sebagai sarana untuk menyalurkan pesan pembelajaran.

Menurut Anderson (Dalam Warsita, 2008: 123). Media dapat dibagai dalam dua kategori, yaitu alat bantu pembelajaran (instructional aids) dan media 
pembelajaran (instructional media). Alat bantu pembelajaran atau alat untuk membantu guru (pendidik) dalam memperjelas materi (pesan) yang akan disampaikan. Oleh karena itu alat bantu pembelajaran disebut juga alat bantu mengajar (teaching aids). Misalnya OHP/OHT, film bingkai (slide) foto, peta, poster, grafik, flip chart, model benda sebenarnya dan sampai kepada lingkungan belajar yang dimanfaatkan untuk memperjelas materi pembelajaran.

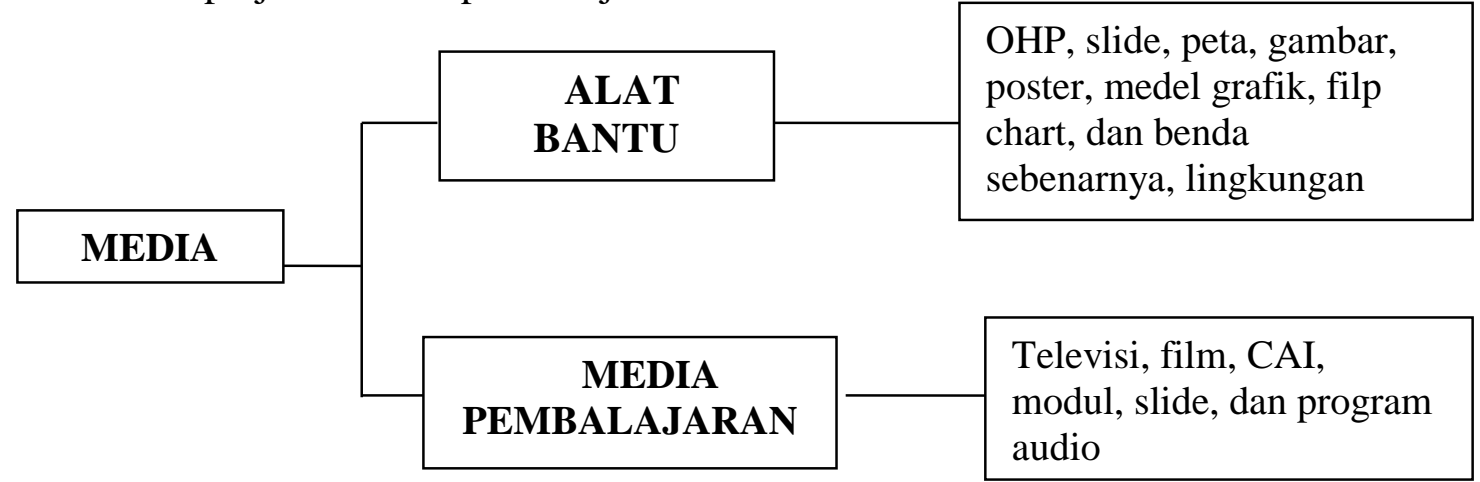

Sudjana dan Rivai (2002: 2), mengemukakan manfaat media pembelajaran dalam proses belajar peserta didik yaitu:

1) Pembelajaran akan lebih menarik perhatian peserta didik sehingga dapat menumbuhkan motivasi belajar.

2) Bahan pembelajaran akan lebih jelas maknanya sehingga dapat lebih dipahami oleh peserta didik sehingga memungkinkannya menguasai dan mencapai tujuan pembelajaran.

3) Metode mengajar akan lebih bervariasi, tidak semata-mata komunikasi verbal melalui penuturan kata-kata oleh guru, sehingga peserta didik tidak bosan dan guru tidak kehabisan tenaga, apalagi bila guru mengajar pada setiap jam pelajaran.

4) Peserta didik dapat lebih banyak melakukan kegiatan belajar sebab tidak hanya mendengarkan uraian guru, tetapi juga aktivitas lain seperti mengamati, melakukan mendemonstrasikan, memamerkan, dll.

Beberapa manfaat praktis dari penggunaan media pembelajaran di dalam proses belajar mengajar sebagai berikut:

1) Media pembelajaran dapat memperjelas penyajian pesan dan informasi sehingga dapat memperlancar dan meningkatkan proses dan hasil belajar.

2) Media pembelajaran dapat meningkatkan dan mengarahkan perhatian peserta didik sehingga dapat menimbulkan motivasi belajar, interaksi lebih langsung antara peserta didik dan lingkungannya.

3) Media pembelajaran dapat mengatasi keterbatasan indera, ruang, dan waktu;

a. Objek atau benda yang terlalu besar untuk ditampilkan langsung di ruang kelas dapat diganti dengan gambar, foto, slide, realita, film, radio, atau model.

b. Objek atau benda yang terlalu kecil yang tidak tampak oleh indera dapat disajikan dengan bantuan mikroskop, film, slide, atau gambar.

c. Kejadian langka yang terjadi di masa lalu atau terjadi sekali dalam puluhan tahun dapat ditampilkan melalui rekaman video, film, foto, slide, disamping secara verbal. 
d. Objek atau proses yang amat rumit seperti peredaran darah dapat dapat ditampilkan secara konkret melalui film, gambar, slide, atau simulasi komputer.

e. Kejadian atau percobaan yang dapat membahayakan dapat disimulasikan dengan media seperti komputer, film, dan video.

f. Peristiwa alam seperti terjadinya letusan gunung berapi atau proses yang dalam kenyataan memakan waktu lama seperti proses kepompong menjadi kupu-kupu dapat disajikan dengan teknik-teknik rekaman seperti time lapse untuk film, video, slide, atau simulasi komputer.

Secara umum, media dapat digolongkan menjadi tiga jenis, yaitu: (1) visual media atau media pandang (2) audio visual atau media dengar, dan (3) audio visual media atau media dengar dan pandang (Suyanto, 2007:102).

Media pandang adalah media yang dapat dipandang atau dilihat dan dapat disentuh oleh peserta didik, missal, gambar, foto, benda sesungguhnya, peta, miniature, dan realita. Sedangkan media dengar (audio) untuk ketrampilan menyimak adalah media yang wacana atau isinya derekam dan didengarkan. Misalnya, radio dan cassette recorder Dan media audio visual adalah perpaduan antara media pandang dan media dengar, misalnya, CD, TV, Film.

Menurut Mabruri (2010:8) Film pendek merupakan film yang durasinya singkat yaitu di bawah 60 menit dan di dukung oleh cerita yang pendek. Dengan durasi film yang pendek, para pembuat film dapat lebih selektif mengungkapkan materi yang ditampilkan melalui setiap shot akan memiliki makna yang cukup besar untuk ditafsirkan oleh penontonnnya.

Menurut Sudjana dan Rivai (1995:102) manfaat penggunaan media film pendek sebagai media pembelajaran, antara lain:

1) Mengembangkan pikiran dan pendapat para peserta didik.

2) Menambah daya ingat pada pelajaran.

3) Mengembangkan daya fantasi peserta didik didik.

4) Menumbuhkan minat dan motivasi belajar.

Film harus dipilih agar sesuai dengan pelajaran yang sedang diberikan. Untuk itu guru harus mengenal film yang tersedia dan lebih dahulu melihatnya untuk mengetahui manfaatnya bagi pelajaran. Sesudah film dipertunjukkan perlu diadakan diskusi, yang juga perlu disisapkan sebelumnya. Ada kalanya film tertentu perlu diputar dua kali atau lebih utuk memperhatikan aspek-aspek tertentu. Agar peserta didik-peserta didik jangan hanya memandang film itu sebagai hiburan, sebelumnya mereka ditugaskan untuk memperhatikan hal-hal tertentu. Sesudah itu dapat ditest berapa banyakkah yang dapat mereka tangkap dari film itu (Nasution, 2011:104).

Esai adalah sebuah tulisan, karangan, analisis, atau penafsiran tentang sesuatu. Kebanyakan dengan topik yang kurang lebih terbatas, dengan luas, gaya dan metode bebas, walaupun pada umumnya dapat dibaca dengan sekali duduk. Menurut ilmu jurnalistik, esai adalah tulisan berupa pendapat seseorang tentang suatu permasalahan ditinjau secara subjektif dari berbagai aspek atau bidang kehidupan (Rahardi, 2006: 27). 
Selain itu, esai adalah karangan prosa yang membahas suatu masalah secara sepintas lalu dari sudut pandang pribadi penulisnya (Depdiknas, 2011). Pengarang esai disebut esais. Esai sebagai satu bentuk karangan dapat bersifat informal dan formal. Esai informal mempergunakan bahasa percakapan, dengan bentuk sapaan "saya" dan seolah-olah ia berbicara langsung dengan pembacanya. Sedangkan esai yang formal, pendekatannya serius. Pengarang menggunakan semua persyaratan penulisan (Parera, 1993: 46).

Dapat disimpulkan dari pendapat beberapa para ahli bahwa definisi esai adalah suatu karangan yang berbuntuk sebuah ide gagasan atau argumen dari sudut pandang dan pendapat penulis dari masalah atau topik yang dipilih atau menarik bagi penulis. Esai ini tidak digolongkan ke dalam karangan ilmiah atau sastra karena sifatnya yang tidak memiliki kaidah, berbeda dengan karangan ilimiah yang memiliki kaidah ilmiahnya dan karangan sastra yang memiliki kaidah sastranya tersendiri. Maka dari itu, esai hanya mempunya subjek yang berperan sebagai pengamat dan objek yang berperan sebagai yang diamati, yang nantinya akan menghasilkan suatu karangan esai.

Esai berbeda dengan teks yang lain, untuk itu berikut ini diuraikan ciri-ciri esai.

1) Berbentuk prosa, artinya dalam bentuk komunikasi biasa, menghindarkan penggunaan bahasa dan ungkapan figur.

2) Singkat, maksudnya dapat dibaca dengan santai dalam waktu dua jam.

3) Memiliki gaya pembeda. Seorang penulis esai yang baik akan membawa ciri dan gaya yang khas, yang membedakan tulisannya dengan gaya penulis lain.

4) Selalu tidak utuh, artinya penulis memilih segi-segi yang penting dan menarik dari objek dan subjek yang hendak ditulis.

5) Memenuhi keutuhan penulisan. Walaupun esai adalah tulisan yang tidak utuh, namun harus memiliki kesatuan, dan memenuhi syarat-syarat penulisan, mulai dari pendahuluan, pengembangan sampai ke pengakhiran.

6) Mempunyai nada pribadi atau bersifat individu, yang membedakan esai dengan jenis karya sastra adalah ciri personal. Ciri personal dalam penulisan esai adalah pengungkapan penulis sendiri tentang pandangannya, sikapnya, pikirannya, dan kepada pembaca.

Adapun sistematika dan unsur kebahasaan dari esai yang dapat diterapkan untuk membuat sebuah esai yang baik.

1) Pendahuluan (Tesis)

Bagian pendahuluan dalam esai adalah sebuah tempat untuk mengungkapkan penyataan tesis atau tesis argumen. Pernyataan tesis memperlihatkan pokok permasalahan yang akan disampaikan oleh penulis esai. Selain itu, tesis bisa juga digunakan untuk menggiring pembaca agar mengetahui pokok esai kita.

2) Konteks

Konteks diartikan sebagai ruang lingkup tulisan secara eksplisit ataupun implisit. Konteks inilah yang membatasi pokok permasalahan agar fokus tidak keluar dari topik yang sedang dikaji.

3) Masalah 
Masalah adalah kejadian atau peristiwa yang tidak sesuai dengan harapan atau keinginan. Sebuah karangan esai yang baik akan mengandung masalah yang aktual sehingga dapat memberikan sesuatu yang baru ke pembaca.

4) Solusi

Solusi adalah usaha penulis untuk menyelesaikan masalah yang ditulis dalam esai karyanya. Penulis esai ingin meyakinkan pembaca agar ide dan gagasan yang dia sampaikan dapat menyelesaikan masalah. Selain itu, penulis juga ingin mengajak pembaca melaksanakan solusi yang disampaikan sehingga masalah dapat terpecahkan dan selesai.

5) Simpulan

Simpulan adalah rangkuman dari pokok masalah dan solusi yang telah disampaikan. Akan lebih baik jika simpulan ditulis dalam 3-5 kalimat yang menggambarkan pendapat Anda tentang topik yang ditulis. Namun, jangan tulis kembali apa yang sudah ditulis sebelumnya karena akan membuat pembaca bosan.

Berikut adalah penjelesan mengenai unsur kebahasaan yang harus ada dalam sebuah esai dengan tidak menyepelekan unsur kebahasaan lain yang sesuai dengan Pedoman Umum Ejaan Bahasa Indonesia (PUEBI).

1) Kata Keterangan/Adverbial Frekuentif

Dalam sebuah teks opini/editorial biasanya digunakan bahasa yang dapat mengekspresikan sikap eksposisi. Agar dapat meyakinkan pembaca, diperlukan ekspresi kepastian, yang bisa dipertegas dengan kata keterangan atau adverbia frekuentatif, seperti selalu, biasanya, sebagian besar waktu,sering, kadangkadang, jarang, dan lainnya.

2) Konjungsi

Kojungsi yang banyak dijumpai pada teks editorial adalah konjungsi yang digunakan untuk menata argumenasi, seperti pertama, kedua, berikutnya, dan sebagainya. Konjungsi kedua yang digunakan untuk memperkuat argumenasi, seperti bahkan, juga, selain itu, lagi pula, sebagai contoh misalnya, padahal, justru dan lain-lain. Konjungsi ketiga yang menyatakan hubungan sebab akibat, seperti sejak, sebelumnya, dan sebagainya. Konjungsi yang menyatakan harapan, seperti agar, suapaya, dan sebagainya.

Banyak uapaya yang dilakukan untuk mengambangkan Penelitian Tindakan Kelas dengan menggunakan media film pendek, satu diantaranya adalah penelitian yang dilakukan oleh Rizki Mertyn Palupi mahasiswa Universitas Negeri Malang melakukan Penelitian Tindakan Kelas (PTK). Penelitian ini bertujuan meningkatkan hasil dan proses menulis cerpen dengan media film pendek pada siswa kelas X-4 SMA Negeri 02 Batu. Desain penelitian ini adalah Penelitian Tindakan Kelas (PTK). Data dalam penelitian ini berupa data proses dan hasil.

Hasil penelitian ini menunjukkan bahwa pada proses pembelajaran siklus I terdapat 11 siswa (42\%) yang mendapat nilai di bawah KKM. Pada proses pembelajaran siklus II, kegiatan siswa selama proses pembelajaran sudah lebih bervariatif dibandingkan siklus I dan semua siswa dikategorikan tuntas. Pada siklus I, 
nilai rata-rata hasil menulis cerpen siswa yaitu 73 dengan kualifikasi cukup baik, sedangkan pada siklus II nilai rata-rata menulis cerpen siswa yaitu 83,3 dengan kualifikasi baik.

Berdasarkan permasalahan yang telah dikemukakan sebelumnya yaitu rendahnya hasil belajar peserta didik atau tidak tercapainya KKM pada pelajaran Bahasa Indonesia materi Teks Esai oleh kelas XII MIPA 6 yang dikarenakan pemilihan media pembelajaran yang kurang tepat. Sehingga peneliti memilih media film pendek untuk upaya meningkatkan hasil belajar peserta didik serendahrendahnya $90 \%$ pada siklus akhir penelitian.

\section{METODE}

Metode yang digunakan adalah metode Penelitian Tindakan Kelas atau Classroom Action Research. Penetilitian Tindakan Kelas (PTK) adalah studi yang dilakukan untuk memperbaiki diri sendiri, pengalaman kerja sendiri, tetapi dilaksanakan sistematis, terencana, dan dengan sikap mawas diri. Penelitian tindakan mengacu pada hal-hal yang dilakukan guru untuk memperbaiki proses pembelajaran yang menjadi tanggung jawabnya. Sebagaimana yang dinyatakan oleh Kunandar (2008:60) bahwa dalam PTK selalu didasarkan pada adanya tindakan (treatment) tertentu untuk memperbaiki proses belajar mengajar dikelas.

Penelitian Tindakan Kelas yang digunakan dalam penelitian ini adalah model penelitian spiral (Arikunto, 2010:74), PTK terdiri atas rangkaian empat kegiatan yang dilakukan dalam siklus berulang. Empat kegiatan utama yang ada pada setiap siklus, yakni (a) perencanaan, (b) tindakan, (c) pengamatan, dan (d) refleksi.

Gambaran umum penelitian, pada penelitian tindakan kelas ini, peneliti berkolaborasi dengan guru mata pelajaran Bahasa Indonesia. Dalam pelaksaaannya, peneliti bertindak sebagai guru yang melaksanakan pembelajaran Bahasa Indonsia khususnya pembelajaran menulis teks esai sedangkaan ibu Wisnu Utamiarti, M.Pd. adalah guru bahasa Indonesia SMA Negeri 1 Pontianak, yang bertindak sebagai pengamat. Penelitian tindakan kelas ini dilakukan di kelas XII MIPA 6 SMA Negeri 1 Pontianak pada Januari sampai dengan Maret 2019.

Rancangan penelitian ini dibatasi pada menulis teks esai, dengan Kompetensi Dasar (KD) 4.13 mengonstruksi sebuah kritik atau esai dengan memperhatikan sistematika dan kebahasaan dan Inkator Pencapaian Kompetensi (IPK) mengonstruksi isi menjadi sebuah teks esai dengan memperhatikan sistematika dan kebahasaan. Rancangan penelitian ini meliputi empat tahap dalam setiap siklusnya, yaitu perencanaan tindakan, pelaksanaan tindakan, pengamatan tindakan dan refleksi tindakan.

Penelitian tindakan kelas ini dilaksanakan dalam 2 siklus yaitu siklus I, dan siklus II. Namun, sebelum melaksanakan siklus terlebih dahulu melakukan prasiklus. Prasiklus bertujuan untuk mengetahui kemampuan Peserta didik menulis teks esai tanpa menggunakan media film pendek. Siklus I bertujuan untuk mengetahui kemampuan peserta didik menulis teks esai dengan menggunakan media film pendek serta sebagai refleksi untuk prasiklu.. Siklus II bertujuan mengetahui peningkatan 
kemampuan menulis teks esai dengan menggunakan media film pendek setelah dilakukan perbaikan terhadap pembelajaran yang didasarkan pada refleksi siklus I.

a. Perencanaan Tindakan

Tahap perencanaan merupakan tahap awal yang merupakan kegiatan untuk menentukan langkah-langkah yang akan dilakukan oleh peneliti untuk memecahkan masalah. Hal yang dilakukan peneliti dalam tahap perencanaan sebagai berikut.

1) Mengidentifikasi masalah pembelajaran menulis teks pada semester sebelumnya.

2) Mendiskusikan pembelajaran yang sesuai dengan upaya untuk meningkatkan kemampuan menulis teks esai.

3) Mempersiapkan media pembelajaran yang akan digunakan.

4) Menganalisis kompetensi dasar menulis teks esai

5) Merancang Rencana Pelaksanaan Pembelajaran (RPP) sesuai materi dengan sintak yang menggambarkan implementasi model pembelajaran kontekstual.

6) Mempersiapkan lembar kerja peserta didik

7) Menyusun racangan evaluasi (sikap, pengetahuan dan keterampilan)

b. Pelaksanaan

Pelaksanaan tindakan pada siklus I merupakan pelakasanaan dari perencanaan yang telah dibuat yang dituangkan dalam Rencana Pelaksanaan Pembelajaran (RPP). Pada tahap ini juga merupakan tahap pengimplementasian penggunaan media film pendek sebagai media penunjang pembelajaran untuk mendapatkan data atau informasi dalam menulis teks esai.

c. Observasi atau Pengamatan

Pada tahap observasi, peneliti mengamati kegiatan peserta didik selama pembelajaran berlangsung. Pada tahap ini observer mengamati dan mencatat temuan tentang:

1) Kesesuaian tindakan guru dalam pembelajaran menulis teks esai dengan menerapkan media film pendek;

2) Situasi pada saat proses pembelajaran;

3) Respons dan perilaku siswa dalam proses pembeajaran;

4) Aktivitas peserta didik sehubungan dengan pembelajaran menulis teks esai dengan menerapkan media film pendek;

5) Aktivitas peserta didik sehubungan dengan media film pendek;

6) Proses dan penilaian dalam pembelajaran.

Data yang diperoleh pada siklus I sebagai acuan dalam perbaikan, serta dijadikan sebagai bahan refleksi.

d. Refleksi

Refleksi merupakan upaya untuk mengkaji yang telah terjadi, tafsiran dengan tindakan perbaikan yang telah dilakukan. Refleksi dilakukan untuk mengetahui kelebihan dan kelemahan pembelejaran yang telah dilaksanankan.

Pada tahap ini peneliti berdiskusi dengan kolaborator untuk mengevaluasi hasil pengamatan yang dilakukan selama pembelajaran. Masalah-masalah yang ditemukan dari pengamatan didiskusikan untuk memperoleh suatu kesimpulan. 
Hasil dari diskusi digunakan untuk langkah dalam perbaikan pada pembelajaran berikutnya.

Data-data penelitian dikumpulkan berdasarkan hasil pengamatan atau observasi, tes, dan dokumentasi. Instrumen pengumpulan data dalam penelitian tindakan kelas ini sebagai berikut.

a. Instumen observasi

Instrumen observasi dalam penelitian ini berisi daftar-daftar jenis kegiatan yang diamati. Instrumen observasi tersebut meliputi instrumen penilaian kemampuan guru (APKG 1) dalam menyusun RPP, instrumen penilaian kemampuan guru (APKG 2) dalam pelaksanaan pembelajaran, instrumen pengamatan media film pendek dan daftar pengamatan sikap peserta didik dalam proses pembelajaran.

b. Tes Tertulis

Tes dilakukan untuk mengetahui kemampuan peserta didik dalam menulis teks esai. Tes tertulis yang digunakan berupa soal esai yang berkenaan dengan menulis teks esai.

c. Dokumen

Dokumen atau arsip dalam peneltian ini mencakup silabus, rencana pelaksanaan pembelajaran, lembar kerja peserta didik, hasil pekerjaan peserta didik, nilai peserta didik yang diberikan guru dan foto.

\section{HASIL DAN PEMBAHASAN}

\section{Hasil Penelitian}

\section{Perencanaan Pelaksanaan Pembelajaran}

Berdasarkan data yang diperoleh dari hasil penilaian observer terhadap RPP yang dibuat oleh guru mengalami peningkatan dari 98\% siklus I menjadi 100\% di siklus II. Di Siklus I pencapaian guru 98\% . pencapaian ini sangat bagus, namun masih terdapat beberapa komponen RPP yang belum lengkap, sehingga pada siklus II di perbaiki dan dilengkapi, sehingga mengalami peningkatan menjadi $100 \%$

\section{Pelaksanaan Pembelajaran Menggunakan Media Film Pendek}

Pelaksanaan pembelajaran menggunakan media film pendek, dilaksanakan dalam dua siklus dengan dua kali pertemuan. Seperti yang telah dijelaskan sebelumnya, penelitian ini menggunakan Penelitian Tindakan Kelas menggunakan model spiral dengan langkah kegiatan yaitu perencanaan, pelaksanaan, observasi dan refleksi.

Dalam pelaksanaannya, guru harus melaksanakan pembelajaran berpacu pada RPP yang telah dibuat dan guru menilai sikap peserta didik. Dalam hal ini sikap peserta didik yang dinilai meliputi (1) Religius, (2) Disiplin, (3) Jujur, dan (4) Bertanggung Jawab.

Kegiatan pelaksanaan pembelajaran menggunakan media film pendek pada tiap siklusnya mengalami peningkatan ke arah yang lebih baik, jika pada seklis I pencapaian guru $81 \%$ maka pada siklus II menjadi $100 \%$. Hal ini menunjukan semua langkah dalam RPP telah dilaksankan dengan baik. 


\section{Evaluasi Hasil Belajar}

Kegiatan pembelajaran menulis teks esai menggunakan media film pendek di kelas XII MIPA 6 pada siklus I dan II dengan kehadiran mencapai 100\%. Perolehan hasil belajar di setiap siklus menunjukan peningkatan yang sangat baik yaitu, siklus I ketuntasan klasikal mencapai $72 \%$ dengan nilai rata-rata 74 dan pada siklus II ketuntasan klasikal mencapai $100 \%$ dengan nilai rata-rata 84.

\section{PEMBAHASAN}

\section{Perencanaan Pelaksanaan Pembelajaran}

Sebelum melaksanakan kegiatan pembelajaran, guru memiliki kewajiban menyusun Rencana Pelaksanaan Pembelejaran (RPP). RPP yang disusun digunakan dalam setiap kali pertemuan atau kegiatan pembelajaran. RPP ini disusun bertujuan untuk mengatur jalannya kegiatan pembelajaran, sehingga pembelajaran menjadi terarah.

RPP yang dikembangkan oleh guru dalam penelitian ini adalah RPP yang menggunakan media film pendek pada Kompetensi Dasar (KD) 4.13 mengonstruksi sebuah kritik atau esai dengan memperhatikan sistematika dan kebahasaan dan Inkator Pencapaian Kompetensi (IPK) mengonstruksi isi menjadi sebuah teks esai dengan memperhatikan sistematika dan kebahasaan.

Berdasarkan pengamatan dari observer terhadap RPP yang disusun oleh guru pada pada siklus I, masih terdapat beberapa kekurangan yaitu, tidak mencantumkan waktu dalam setiap kegiatan, tidak terdapat pembentukan kelompok dan kegiatan berdiskusi, prinsip pendekatan saintific dan 4C serta tidak memunculkan sikap yang akan dinilai dalam proses pembelajaran dan kekurangan yang terdapat pada siklus I telah dilengkapi pada siklus II.

\section{Pelaksanaan Pembelajaran Menggunakan Media Film Pendek}

Pelaksanaan penelitian tindakan kelas dalam pembelajaran menulis teks esai dengan menggunakan media film pendek pada peserta didik kelas XII MIPA 6, SMA Negeri 1 Pontianak dilaksanakan dalam dua siklus. Tiap siklus dilaksanakan dalam satu kali pertemuan dengan waktu belajar 2X45 menit, disesuaikan dengan jadwal aktif sekolah.

Kegiatan pelaksanaan pembelajaran pada siklus I belum terlaksana sepenuhnya, terdapat beberapa kegiatan pembelajaran yang tidak dilakukan oleh guru, antara lain.

a) Guru belum menyampaikan manfaat mempelajari teks esai

b) Guru tidak mengaitkan materi yang akan dipelajari dengan materi pada pertemuan ssebelumnya

c) Guru masih menggunakan pertanyaan terbuka yang menyebabkan peserta didik menjawab pertanyaan secara serentak.

d) Guru belum memberikan kesempatan kepada peserta didik untuk bertanya.

e) Guru belum menyimpulkan hasil pembelajaran pada kegiatan penutup.

1) Pengamatan terhadap media pembelajaran yang digunakan. 
Media pembelajaran yang digunakan oleh guru yakni film pendek yang berjudul "Berubah", berdasarkan pengamatan observer film yang dipilih pada sikulus I kurang menaarik minat peserta didik, sehingga menyebabkan peserta didik tidak memperhatikan dengan serius.

Adapun langkah-langkah pembelajaran yang terlewati atau yang tidak dilaksanakan oleh guru pada siklus I telah dilaksanakan atau diperbaiki pada siklus II dan mengganti film pendek pada pembelajaran siklus II.

Pengamatan terhadap sikap peserta didik dalam mengikuti pembelajaran. Berdasarkan pengamatan guru pada pembelajaran siklus I dan II sikap peserta didik pada indikator "cukup" sangat menurun dengan rincian sebagai berikut.

a) Religus

Siklus I 14\% sebanyak 5 peserta didik, siklus II menurun $0 \%$

b) Disiplin

Siklus I 10\% sebanyak 10 peserta didik., siklus II menurun 9\% sebanyak 3 peserta didik.

c) Jujur

Siklus I 26\% sebanyak 9 peserta didik., siklus II menurun $6 \%$ sebanyak 2 peserta didik.

d) Bertanggung Jawab

Siklus I 32\% sebanyak 11 peserta didik, siklus II menurun 0\%

\section{Evaluasi hasil belajar}

Pada siklus I persentase peserta didik yang tuntas dan belum tuntas berdasarkan Kriteria Ketuntasan Minimal (KKM) Bahasa Indonesia yang telah ditentukan di SMA Negeri 1 Pontianak yaitu 75. Jumlah peserta didik kelas XII MIPA 6 sebanyak 35 peserta didik dengan rincian nilai sebanyak $72 \%$ peserta didik sudah mencapai nilai tuntas pada interval $75-84$, sedangkan peserta didik belum mencapai ketuntasan pada interval $67-74$ sebesar $14 \%$ dan interval 0 -66 sebesar $14 \%$.

Setelah mengganti film pendek pada siklus II hasil belajar menunjukkan persentase peserta didik dengan rincian nilai sebanyak $83 \%$ peserta didik sudah mencapai nilai tuntas pada interval 75-84 dan pada interval 85-100 sebanyak 17\%.Berdasarkan data tersebut, nilai peserta didik sudah menunjukkan peningkatan dari pembelajaran pada siklus I dan mencapai ketuntasan klasikal 100\%, dengan rincian sebagai berikut.

Berdasarkan evaluasi hasil belajar siklus II di atas, kemampuan peserta didik dalam menulis teks esai dengan memperhatikan aspek struktur teks, kaidah kebahasaan dan penuulisan (mekanik) dijabarkan sebagai berikut.

a. Struktur Teks

Struktur teks dalam teks esai terdiri atas, tesis, konteks, masalah, solusi, dan simpulan. Dari hasil evaluasi perolehan skor peserta didik pada aspek struktur bagian tesis terdapat 14 perserta didik memperoleh skor 4 dan 21 peserta didik memperoleh skor 3 . 


\section{Jambura Journal of Linguistics and Literature \\ Vol. I, No. I, Hal. I - 13, Juni 2020 \\ https://ejurnal.ung.ac.id/index.php/ijll}

Pada bagian konteks, terdapat 15 peserta didik yang memperoleh skor 4 dan 20 peserta didik memperoleh skor 3 . Pada bagian malasah terdapat 13 peserta didik yang memperoleh skor 4 dan 22 peserta didik memperoleh skor 3.

Pada bagian solusi, terdapat 17 peserta didik yang memperoleh skor 4 dan 18 peserta didik memperoleh skor 3. Pada bagian simpulan, terdapat sembilan peserta didik yang memperoleh skor 4 dan 26 peserta didik memperoleh skor 3 .

b. Kaidah Kebahasaan

Kaidah kebahasaan yang dinilai pada teks esai sesuai dengan materi yang terdapat dalam buku siswa dan buku guru yaitu adverbia dan konjungsi. Dari hasil evaluasi perolehan skor peserta didik pada aspek kaidah kebahasaan bagaian adverbia terdapat 10 peserta didik memperoleh skor 4 dan 25 peserta didik memperoleh skor 3. Pada bagian konjungsi terdapat 14 peserta didik memperoleh skor 4 dan 21 peserta didik memperoleh skor 3.

c. Penulisan (Mekanik)

Penulisan yang dinilai pada teks esai meliputi penggunaan tanda baca, penggunaan kata dan kalimat. Dari hasil evaluasi perolehan skor peserta didik pada aspek penulisan (mekanik) terdapat tujuh peserta didik memperoleh skor 4 dan 28 peserta didik memperoleh skor 3.

\section{SIMPULAN}

Setelah menerapkan pembelajaran menggunakan media film pendek di kelas XII MIPA 6 SMA Negeri 1 Pontianak, terjadi penigkatan kemampuan guru dalam menyusun Rencanaa Pelaksanaan Pembelajaran (RPP) di setiap siklusnya dari $98 \%$ menjadi $100 \%$, pelaksanan pembelajaran menajdi lebih menyenangkan dengan pemilihan film pendek yang tepat, setiap langkah pembelajaran terlaksana dengan baik dan menunjukan peningkatan dari $81 \%$ menjadi $100 \%$ diikuti dengan perubahan sikap perserta didik yang selalu meningkat kearah yang baik. Serta meningkatkan hasil belajar peserta didik. Hal ini terlihat dari skor rata-rata menulis teks esai sebelum diberi tindakan atau pada prasiklus adalah 72, dengan ketuntasan klasikal 51\%, setelah diberi tindakan siklus I skor rata-rata menjadi 72, dengan ketuntasan klasikal $72 \%$. Skor rata-rata menulis teks esai pada siklus II yaitu 84, dengan ketuntasan klasikal $100 \%$. Secara keseluruhan pada akhir siklus II ini semua aspek dan kriteria menulis teks esai mengalami peningkatan yang cukup signifikan.

\section{DAFTAR PUSTAKA}

Arief. S. Sadiman. dkk. 1996. Media Pendidikan: Pengertian, Pengembangan dan Pemanfaatanya. Jakarta: PT Raya Grafindo Persada.

Arikunto. S. 2010. Penelitian Tindakan Kelas. Jakarta: Bumi Aksara.

Arief. S. Sadiman. dkk. 1996. Media Pendidikan: Pengertian, Pengembangan dan Pemanfaatanya. Jakarta: PT Raya Grafindo Persada.

Arikunto. S. 2010. Penelitian Tindakan Kelas. Jakarta: Bumi Aksara.

Nasution. 2011. Teknologi Pendidikan. Jakarta: Bumi Aksara.

Parera, J.D. 1992. Menulis Tertib dan Sistematik. Jakarta: Erlangga. 


\section{Jambura Journal of Linguistics and Literature \\ Vol. I, No. I, Hal. I - 13, Juni 2020 \\ https://ejurnal.ung.ac.id/index.php/ijll}

Rahardi. F. 2006. Panduan Lengkap Menulis Artkel, Feature dan Esai. Modul Dasar Pelatiahan Jurnalistik Bagi Pemula Dilengkapi Juga dengan Aneka Contoh Tulisan. Jakarta: PT. Kawan Pustaka.

Sudjana, Nana dan Ahmad Rivai. 1995. Cara Belajar Siswa Aktif dalam Proses Belajar Mengajar. Bandung: Sinar Baru Algesindo.

Sudjana, Nana dan Ahmad Rivai. 2002. Media Pengajaran. Bandung: Sinar Baru Algesindo.

Suyanto. 2007. Tantangan Profesional Guru di Era Global. Yogyakarta: Dirjen Mendikdasmen Departemen Pendidikan Nasional.

Warsita, Bambang. 2008. Teknologi Pembelajaran: Landasan dan Aplikasinya. Jakarta: Rineka. 